\title{
EGFR NM_005228.3:c.2250_2273del24
}

National Cancer Institute

\section{Source}

National Cancer Institute. EGFR NM 005228.3:C.2250 2273del24. NCI Thesaurus. Code C98575.

A deletion of 24 nucleotides from the coding sequence of the EGFR gene from position 2250 through 2273. 